\title{
Electric microcurrent in the restoration of the skin undergone a trichloroacetic acid peeling in rats 1
}

\author{
Microcorrente elétrica na restauração da pele submetidos ao peeling de ácido \\ tricloroacético em ratos
}

\section{Vilma Natividade Silva Santos ${ }^{2}$, Lydia Masako Ferreira ${ }^{3}$, Edith Kawano Horibe ${ }^{4}$, Ivone da Silva Duarte 4}

1. Study developed in the Post-Graduation Program of Recovering Plastic Surgery of the Federal University of São Paulo (UNIFESP) - Paulista School of Medicine (EPM). São Paulo - Brazil.

2. Physiotherapist member of Regional Physiotherapy and Occupational Therapy Council (Crefito). Master of Sciences.

3. Full Professor and Head of the Discipline Plastic Surgery of the Department of Surgery, and Coordinator of the PostGraduation Program of Recovering Plastic Surgery UNIFESP-EPM.

4. Collaborator Professor of the Discipline Plastic Surgery UNIFESP-EPM.

\begin{abstract}
PURPOSE: To investigate the influence of neuromuscular electric stimulation by microcurrent (MENS Microcurrent Electric Neuromuscular Stimulation) in the restoration of the skin of rats undergone trichloroacetic acid (TCA).

METHODS: Thirty-two hairless, male, adult rats were divided into two groups (with 16 animals each). In the Control Group (G1) the application of microcurrent was simulated 48 hours after the peeling. In the Experimental Group (G2) MENS was applied 48 hours after the TCA peeling, each 48 hours up to the Day 21 , under the frequency of $0.5 \mathrm{~Hz}$, intensity of $50 \mathrm{~mA}$, and lasting 20 minutes. The area of the lesion was evaluated on Days 7, 14, and 21 after-peeling by the Paper Template Method, and on Day 21 the histological analysis was performed.
\end{abstract}

RESULTS: On microscopy changes were seen in the fibroblasts amount and structure, and in the collagen of the experimental group, with statistically significant difference $(\mathrm{p}<0,01)$

CONCLUSION: MENS reduced the period of restoration of the area undergone TCA peeling in rats skin.

KEY WORDS: Trichloroacetic acid. Wound healing. Electric stimulation. Chemexfoliation. Rats.

\section{RESUMO}

OBJETIVO: Investigar a influência da estimulação elétrica neuromuscular por microcorrente (MENS Microcurrent Electric Neuromuscular Stimulation) na restauração da pele de ratos submetidos ao peeling com ATA(ácido tricloroacético).

MÉTODOS: Foram utilizados 32 ratos hair less machos adultos, separados em dois grupos (com 16 animais cada).No Grupo Controle (G1) foi simulada a aplicação da microcorrente 48 horas após o peeling . No Grupo Experimental (G2) a MENS foi aplicada 48 horas após o peeling com ATA, realizada, a cada 48 horas, até o $21^{\circ}$ dia, com freqüência de $0,5 \mathrm{~Hz}$, intensidade de $50 \mu \mathrm{A}$ e duração de 20 minutos. Avaliou-se a área da lesão no $7^{\circ}, 14^{\circ}$ e $21^{\circ}$ dia pós-peeling, com o Método Gabarito de Papel, e no $21^{\circ}$ dia foi realizada a análise histológica. 
RESULTADOS: Na microscopia foram observadas modificações na quantidade e na estrutura dos fibroblastos, e no colágeno do Grupo Experimental em relação ao Grupo Controle. Pelo Método Gabarito de Papel, observou-se redução do tempo para a restauração total da área de lesão no grupo experimental , com diferença de significância estatística de $(\mathrm{p}<0,01)$.

CONCLUSÃO: A MENS diminuiu o período de restauração da área submetida ao peeling com ATA em pele de ratos.

Descritores: Ácido tricloroacético. Cicatrização de feridas. Estimulação elétrica. Abrasão química. Ratos.

\section{Introduction}

Trichloroacetic acid (TCA) is being used in chemical peelings, with the aim of treating pigmentation irregularities and changes, on the cutaneous surface and dermatosis with unesthetical consequences ${ }^{1}$. The patient who undergoes TCA peeling passes by a discomfort and even suffering during the period of skin restoration. Barne ${ }^{2}$ stated in his papers, that a cutaneous wound surface is electrically positive when it is compared to circumjacent skin. Based on these concepts, Assimacopoulos ${ }^{3}$ showed that microcurrent electrical neuromuscular stimulation (MENS), when applied for treating ulcers by venous impairment, accelerated the healing process, besides having stimulated the conjunctive tissue growth ${ }^{3}$. A study carried out with rat skin showed the efficacy of MENS on the increase of adenosine triphosphate (ATP) generation, which makes evident the increase of protein synthesis, as well as the increment of transportation by plasma membrane ${ }^{4}$. ATP is a key factor within the healing process besides being the main energy source of the cell. A higher arrival of ATP is demanded to control primary functions of damaged cells, such as the vital minerals (sodium, potassium, magnesium, calcium) transportation towards inside and outside the cell ${ }^{4}$. This study objective was to investigate the influence of microcurrent electrical on the skin restoration of rats undergone TCA peeling.

\section{METHODS}

\section{Sample}

Thirty-two exogamic, male, adult Wistar-EPM rats (hairless), aging between 3 and 5 months, with average weight 300 grams, coming from Experimental Research Development Center (CEDEME UNIFESP-EPM). The animals were designed to 2 groups containing 16 animals each: Control Group (G1) and Experimental Group (G2).

\section{Procedures}

Animals were undergone general anesthesia with sodium pentobarbital ( $40 \mathrm{mg} / \mathrm{kg}$ ) via intraperitoneal. Positioned in ventral decubitus on a straight position, a $18 \mathrm{~cm}^{2}$ area on the dorsal position was laterally at left delimited from the animal's fourth thoracic vertebra. The peeling was performed with 50\% TCA and, in each animal, $0.2 \mathrm{~mL}$ was used by the technique of uninterrupted single passage over the skin. In the G1, the animals were treated with MENS simulation, and they were put in sedation by ethylic ether inhalation. Conductor rubber electrodes with a $2 \mathrm{~cm}$ diameter were placed around the lesion and the MENS device was not turned on. In the group G2 MENS device, brand Emdutos ${ }^{\mathrm{R}}$ was adjusted in the frequency of 0.5 $\mathrm{Hz}$, intensity of $50 \mu \mathrm{A}$, type pulsing wave, for 20 minutes 48 hours after TCA peeling and, continuously, each 48 hours the procedure was repeated, up to the Day 21. For evaluating the animal's restored area, the lesion was transferred on translucent tracing paper and the Paper Template Method was used ${ }^{5}$. A 6 x 3 $\mathrm{cm}(18 \mathrm{~cm} 2)$ fragment corresponding to the treated area was cut and weighted on a precision scale with $\mathrm{a}+/-0.001 \mathrm{~g}$ error. The percentages of the animal's lesion area were calculated on Days 7, 14, and 21. Results were assessed by a statistical study with Variance of Repeated Measure ${ }^{6}$, with standard error $0.05 \%$, with the software SPSS for Windows ${ }^{\circledR}$, version 10. In Day 21, from both groups $7 \mathrm{~mm}$ circular fragments of tissue were removed from the center of the TCA treated area by a $7 \mathrm{~mm}$ punch. These fragments were preserved into a $10 \%$ formaldehyde solution and sent to be processed in the histology laboratory by Eosine Hematoxylin (HE) technique. For microscopic analysis, light microscopy 
with 100 times magnification was used. Blades were examined together with the Discipline Pathology UNIFESP-EPM. At the end of the experimental procedure euthanasia was used by transection of the main cervical blood vases, after anesthesia with pentobarbital via intraperitoneal. This study was approved by the UNIFESP-EPM Ethics Committee under the research protocol No. 250/01.

\section{Results}

Animals evolved without any complication during the observation period.

In the histological evaluation of group G1 epithelial regeneration, healing scar and epidermal fibrosis (Figure 1) were seen, as well as fibroblasts proliferation with ovoid and rounded nuclei, besides thin collagen and dissociated fibers.

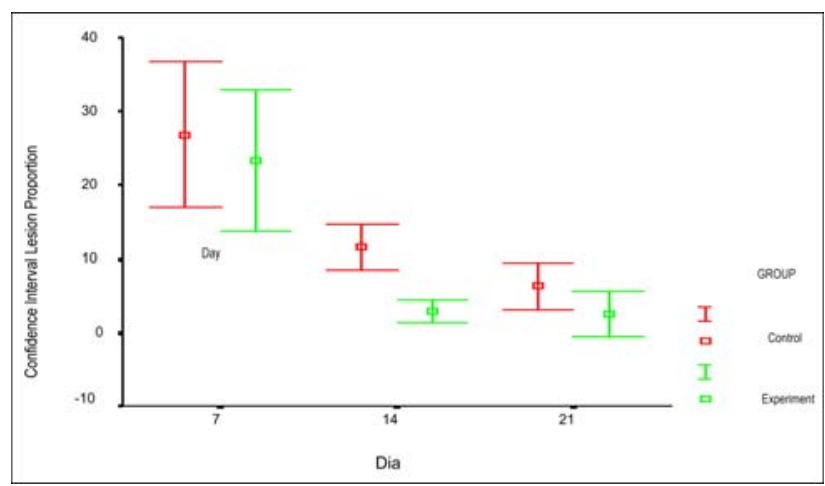

FIGURE 1 - Significant difference, between the lesion proportion and time, in Groups G1 I and G2 I.

TABLE 1 - Means of percentages of lesion area in rats. Statistical difference was significant for experimental group between days 7 and 14, showing $\mathrm{p}=0.033$.

EVALUATION DAYS CONTROL (\%) EXPERIMENT (\%)

$\begin{array}{ccc}\mathbf{7}^{\mathbf{o}} & 26,81 & 23,24 \\ \mathbf{1 4}^{\mathbf{o}} & 11,59 & 2,82 \\ \mathbf{2 1}^{\mathbf{0}} & 6,30 & 2,53\end{array}$

$\mathrm{P}=0.033$ when compared with the respective control (G1)

In group G2 a homogeneous epithelial regeneration, more evident healing scar, and epidermis thickening were seen. The amount of fibroblasts was greater than the one in Group G1 besides presenting more compact and eosinophitic collagen (Figure 2).

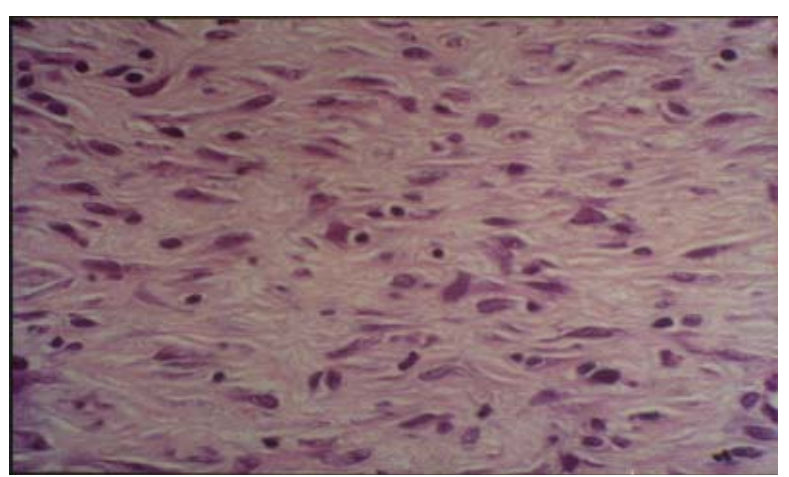

FIGURE 2 - Photomicrograph of the rat skin day 21 after peeling using TCA, in the control group (G1) (HE, 100X), fibroblasts with circular and oval nuclei,dissociated fibers.

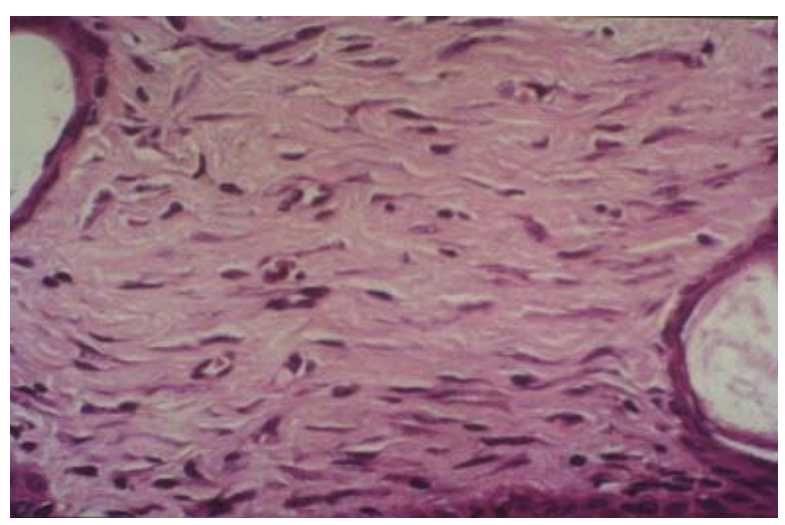

FIGURE 3 - Photomicrograph of the rat skin day 21 post peeling using TCA, in the experimental group (G2) (HE, 100x). There is an increased number of fibroblasts, with compact eosinophitic colagen fibers.

\section{Discussion}

In the scrutinized literature we did not find a standard procedure which may reduce discomfort of the patient undergone deep TCA peeling. That is why this study standardized a procedure by using physical means in order to alleviate the discomfort during the restoration period, as well as the patient's withdrawal from his/her social life. In medicine, electrotherapy is used to manage symptoms, not as a curative measure. Cheng et $\mathrm{al}^{4}$, proved that a low amperage current stimulates the physiologic activity of damaged cells. Hairless rats were used in the experiment so that hair does not interfere on the lesions observation when their skin was being restored. There are several studies $^{3,7,8,9,10,11,12,13}$, in which their authors applied MENS on the healing process, but not one report about post-peeling procedures was found. The present study was based on literature and on a pilot plan with 6 animals, from which TCA concentration, 
frequency, equipment intensity, and application time were defined. In terms of stimulating effects of electric currents and ATP formation on cutaneous tissue, there are reports stating that during the MENS application electrons react with water molecules by their cathodic side (to produce hydroxyl ions), while protons are formed in the anodic side ${ }^{4}$. Thus, between anodic and cathodic interfaces a protons potential gradient run through the tissue, so creating an electric field. As a consequence, protons being influenced by both electric field and concentration difference should move from anode to cathode, provided that protons formation on anodic interface is present. If protons consumption in cathodic side is the same, system's $\mathrm{pH}$ (medium and tissue) remains without any interference. Substract oxidation, which is followed by protons migration through membranes, may be similarly electrically stimulated by protons induced current which activates a feedback process. Cheng et $\mathrm{al}^{4}$ showed that DNA metabolism is not affected by electrical stimulation and inhibition effects, by suggesting that stimulating and inhibiting effects over the protein synthesis activity occur independently of the effects on the transition process between anode and cathode. Another interpretation for MENS in the restoration process is due to the $\mathrm{H}+$ ions migration, since they are responsible for preparing the ATP obtaining process, and afterwards by its posterior storage into cytoplasm. In spite of some authors state the importance of the electrodes polarity change on the lesion ${ }^{7,8}$, the present study disagrees, since it was already verified in the pilot plan that, because it is a pulse current, having anode and cathode around the lesion is important. The present study also suggested that periods for evaluation of lesion areas percentages should be lower, in order to achieve a higher accuracy in the restoration time when using MENS. New studies, with different kinds of electrical currents and other physical agents should be carried out aiming to contribute towards this investigation area. Thus, the importance of other studies on MENS, but directed to the human skin restoration was evidenced, since the existing literature is still scarce.

\section{Conclusion}

Microcurrent Electrical Neuromuscular Stimulation (MENS) reduces the restoration lengh of rats skin undergone TCA peeling.

\section{References}

01. Horibe E K. Estética clínica \& cirúrgica. In: Horibe EK. Uso do ácido tricloroacético. 1ed. Rio de Janeiro: Revinter; 2000. p 47-60.

02. Barnes TC. Healing rate of human skin determined by measurement of the electrical potential of experiment abrasions. Am J Surg 1945;69:82-8.

03. Assimacopoulos D. Wound healing promotion by the use of negative electric current. Am Surg 1968; 4:423-31.

04. Cheng N, Van Hoff H, Bockx E. The effect of electric currents on ATP generation protein synthesis, and membrane transport in rat skin. Clin Orthop 1982;171:26472.

05. Sasaki GH, Pang CY. Pathophysiology and skin flaps raised on expanded pig skin. Plast Reconstr Surg 1984; 4:59-69.

06. Neter, J. Applied linear statistical models. 4ed. Chicago: IRWIN; 1996.

07. Alvarez OM, Mertz PM, Smerbeck RV. The healing of superficial wounds in stimulated by external electrical current. J Invest Dermatol 1983;81:144- 8.

08. Carley PJ, Wainaipel SF. Electrotherapy for acceleration of wound healing: low intensity direct current. Arch Phys Med Rehabil 1985;66:443-6.

09. Brown M, Gogia PP. Effects of high voltage stimulation on cutaneous wound healing in rabbits. Phys Ther 1987;67:662-7.

10. Dunn MG. Wound healing using a collagen matrix: effect of DC electrical stimulation. J Biomed Mater Res Appl Biomat 1988;22:191-206.

11. Kloth LC, Feedar JA. Acceleration of wound healing with high voltage monophasic pulsed current. Phys Ther 1988; 68:503-8.

12. Mertz PM, Davis SC, Cazzaniga AL, Cheng K, Reich JD, Eaglstein VM. Electrical stimulation: acceleration of soft tissue repair by varying the polarity. Wounds 1993;5:1539.

13. Vodovnik L, Karba R. Treatment of chronic wounds by means of electric and electromagnetic fields. Rev Med Biol Eng Comput 1992;30:257-66.

\section{Correspondence:}

Vilma Natividade Silva Santos

Departamento de Cirurgia Plástica

Rua Napoleão de Barros, 715

04024-002 São Paulo - SP Brazil

Tel: (55 11) 5576-4065 / 5576-4118

lydia.dcir@epm.br

Received: May 4, 2004

Review: June 14, 2004

Accepted: July 6, 2004

Conflict of interest: none

Financial source: none 
How to cite this article:

Santos VNS, Ferreira LM, Horibe EK, Duarte IS. Electric microcurrent in the restoration of the skin undergone a trichloroacetic acid peeling in rats. Acta Cir Bras [serial online] 2004 Sept-Oct;19(5). Available from URL: http://www.scielo.br [also in CD-ROM].

*Color figures available in www.scielo.br/acb 